\title{
MENINGKATKAN HASIL BELAJAR LOMPAT MELALUI AKTIVITAS LOMPAT TALI DENGAN PENERAPAN GAYA PRACTISE
}

\author{
Pathurohman ${ }^{1}$ R Wibowo ${ }^{1}$ \\ Universitas Pendidikan Indonesia ${ }^{1}$ \\ email: ricky_wibowo@upi.edu
}

\begin{abstract}
Abstrak
Penelitian ini bertujuan untuk mengetahui apakah melalui aktivitas lompat tali dengan penerapan gaya practice dapat meningkatkan hasil belajar siswa kelas III SDN Sukarela 01. Metode penelitian yang digunakan dalam penelitian ini yaitu dengan Penelitian Tindakan Kelas. Dalam penggunaan metode ini peneliti menggunakan dua siklus dan dalam setiap siklus terdiri dari dua tindakan. Subjek penelitian ini adalah siswa kelas III yang berjumlah 32 orang, terdiri dari 20 orang putra dan 12 orang putri. Instrumen penelitian yang digunakan dalam penelitian ini yaitu dengan observasi, catatan lapangan dan dokumentasi. Hasil penelitian menunjukan bahwa melalui aktivitas lompat tali dapat meningkatkan hasil belajar lompat pada siswa. Hasil peningkatan tersebut ditunjukan dari peningkatan hasil belajar rata-rata siswa pada setiap siklusnya. Rata-rata hasil pada observasi awal pada aspek kognitif adalah 37,5, siklus 1 tindakan 1 adalah 40,1, siklus 1 tindakan 2 adalah 50,8, sedangkan siklus 2 tindakan 1 adalah 61,7, dan siklus 2 tindakan 2 adalah 76,8. Sedangkan pada aspek afektif observasi awal rata-rata sebesar 39,9, siklus 1 tindakan 1 adalah 45,6, siklus 1 tindakan 2 adalah 63,5, siklus 2 tindakan 1 adalah 63,5, siklus 2 tindakan 2 adalah 77,1. Dan untuk aspek psikomotor observasi awal rata-rata sebesar 38,28, siklus 1 tindakan 1 adalah 44,54, siklus 1 tindakan 2 adalah 50,46, siklus 2 tindakan 1 adalah 60,48, siklus 2 tindakan 2 adalah 76,56. Berdasarkan hasil analisis data penelitian yang penulis teliti dapat disimpulkan bahwa melalui aktivitas lompat tali dengan penerapan gaya practice dapat meningkatkan hasil belajar siswa kelas III SDN Sukarela 01.
\end{abstract}

Kata Kunci : hasil belajar lompat, aktivitas lompat tali, gaya mengajar Practice

\section{PENDAHULUAN}

Salah satu tujuan pendidikan jasmani ialah mengembangkan keterampilan gerak. Dengan berkembangnya bermacam-macam karakterisktik jasmani dan kematangan anakanak dalam mengembangkan kecakapan untuk membentuk keterampilan gerak. Faktor kematangan anak ini bergantung pada derajat kemampuan perkembangan anak yang akan mempengaruhi terhadap jenis keterampilan dan berapa banyak yang dapat dikuasi. Pada dasarnya gerakan pada manusia adalah gerakan berjalan, berlari dan melompat. Memiliki keterampilan ini merupakan bagian penting untuk partisipasi yang menyenangkan dan ketertarikan seumur hidup dalam gaya hidup yang aktif (Quinn, 2010). Penguasaan 
keterampilan gerak fundamental dapat memiliki efek langsung pada kesehatan anak maupun remaja. Penelitian telah menunjukkan bahwa anak-anak dan remaja dengan kemampuan gerakan dasar yang lebih baik cenderung lebih aktif secara fisik, memiliki kebugaran aerobik yang lebih tinggi (Okely et al, 2001). Keterampilan gerak fundamental mengacu pada gerakan yang sederhana dan merupakan fondasi untuk berpartisipasi atau melakukan berbagai jenis aktivitas.

Lompat adalah suatu gerakan mengangkat tubuh dari suatu titik ke titik lain yang lebih jauh atau tinggi dengan ancang-ancang lari cepat atau lambat dengan menumpu satu kaki dan mendarat dengan kaki/anggota tubuh lainnya dengan keseimbangan yang baik (Dikti, 2012: 19). Tujuan guru mengajarkan lompat adalah dapat memberi pengenalan gerakan fundamental yang diharapkan memiliki keterampilan dasar yang kelak dikembangkan lebih lanjut. Pengembangan gerak lompat adalah mengajarkan anak melompat ke depan (jauh) dengan sikap gerak lompat yang benar, yaitu membengkokkan lutut, mengayunkan lengan, dan melakukan gerak perluasan/ekstensi (Sujiono dkk. 2007: 6.25). Sedangkan menurut Widodo (2010), macam-macam bentuk peningkatkan keterampilan gerak dasar lompat yaitu: 1) lompat ke atas setinggi-tingginya meraih sesuatu di atas, dengan berulang-ulang, 2) lompat ke atas kedepan, dengan berulangulang.

Kegiatan belajar mengajar tidaklah mudah. Guru yang efektif memiliki pengetahuan dan keahlian sedangkan guru yang kurang efektif tidak memilikinya. Jenis pengetahuan dan keterampilan tidak dikembangkan dari buku-buku bacaan atau belajar tentang mengajar saja (Phelps, 2009; Ball \& Forzani, 2009). Proses belajar mengajar, kegiatan yang paling strategis adalah sangat tergantung pada pemilihan dan penepatan strategi pembelajaran. Moston (1994) telah mengidentifikas gaya mengajar yang dapat digunakan guru penjas. Gaya-gaya mengajar tersebut terentang dari mulai yang berorientasi pada guru sampai pada yang berorientasi pada siswa. Gaya Komando (The Command Style), Gaya Tugas (The Practice Style), Gaya Resipkoral (The Reciprocal Style), Gaya Mandri Berstruktur (Invidual Programmed Instruction), Gaya Diskoveri Terbimbing (Guided Discovery), Gaya Pemecahan Maslah (Problem Solving). Dalam gaya-gaya pembelajaran ini bisa diterapkan untuk bahan acuan pembelajaran kepada siswa. Dalam aktivitas lompat tali, gaya mengajar yang diterapkan kepada siswa harus disesuaikan dengan tingkat perkembangan siswa. Pada usia sekolah dasar khususnya kelas III sekolah dasar, berdasarkan hasil observasi dilapangan peneliti menemukan bahwa rata-rata siswa-siswa sekolah dasar kelas III belum mampu melakukan aktivitas lompat tali. Oleh karena itu, nampaknya dengan menarapkan gaya practice akan cocok bila diterapkan pada pembelajaran aktivitas lompat melalui aktivitas lompat tali.

Beberapa peneliti mempelajari efek dari lompat tali pada kebugaran fisik yang berhubungan dengan kesehatan pada siswa dengan gangguan intelektual ringan atau gangguan penglihatan, dan menemukan bahwa lompat tali secara signifikan meningkatkan keseimbangan, daya tahan kardiovaskuler, kekuatan otot, komposisi tubuh, dan fleksibilitas (Yeh, 2007; Tsai, 2009; Chen, 2010). Mojtaba B. G., Parivash N. and Hossein S. (2014) telah melakukan penelitian eksperimen dengan tujuan untuk menguji efek dari program lompat tali terhadap keterampilan motorik kasar pada siswa laki-laki kelas 4 (empat) Sekolah Dasar. Hasil penelitian menunjukkan bahwa ada perbedaan yang signifikan dalam keterampilan motorik kasar dan sub-tes keseimbangan, kekuatan dan koordinasi bilateral dalam speedy dan demonstrasi. Di sisi lain, berdasarkan temuan dari 
penelitian ini kedua program lompat tali memiliki efek signifikan pada keterampilan motorik kasar subyek (siswa yang diteliti). Namun, hasil penelitian menunjukkan bahwa tidak ada perbedaan yang signifikan dilaporkan dalam meningkatkan kecepatan dan kelincahan antara tiga kelompok. Berdasarkan hasil penelitian tersebut, penulis mencoba menambah khasanah penelitian dengan mengembangkan aktivitas lompat tali berdasarkan tingkat kemampuan siswa dan dikemas dalam setting gaya mengajar practice.

\section{METODE PENELITIAN}

Rancangan Penelitian Tindakan Kelas yang digunakan dalam peneltian ini adalah model yang dikembangkan oleh Kurt Lewin. Penelitian tindakan kelas mengikuti suatu siklus dimana tiap siklus terdiri dari langkah- langkah berikut: (1) Perencanaan (Planing), (2) Aksi atau tindakan (Action), (3) Observasi (Observing), (4).Refleksi (Reflecting)". Lebih jelasnya disajikan pada gambar dibawah ini:

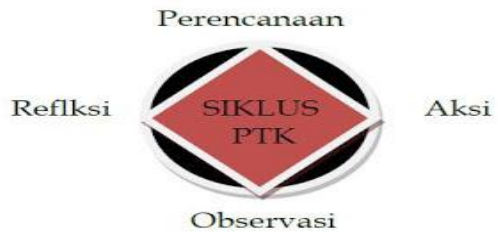

\section{Gambar 1. Desain PTK Model Kurt Lewin \\ (Sumber: http://gurukumiisjtg.blogspot.co.id)}

\section{Subjek dan Tempat}

Penelitian ini dilaksanakan di SDN Sukarela Kota Bandung pada siswa kelas III (tiga) dengan jumlah siswa 32 orang yang terdiri dari 20 siswa putra dan 12 siswa putri. Peneliti memilih lokasi tersebut dikarenakan peneliti telah mengetahui kondisi dan karakteristik dari peserta didik dan mudah dalam mengkondisikan setting penelitian.

\section{Instrumen Penelitian}

Berkaitan dengan permasalahan yang diteliti, maka penulis mengambil aspek keterampilan gerakan dasar lompat. Hal ini dikarena permasalahan penelitian yang akan diteliti yaitu aspek gerak dasar lompat saja yang meliputi posisi sikap awalan, sikap melayang vertical, dan gerakan sikap akhir mendarat. Instumen penelitian diadaptasi dari Elder dalam Fundamental Motor Skills: A Manual for Classroom Teachers (2009)

Untuk lebih jelasnya mengenai instrument yang dipergunakan dalam penelitian ini dapat dilihat pada tabel dibawah ini: 
Tabel 2. Format Lembar Observasi Siswa

\begin{tabular}{|c|c|c|c|c|c|c|}
\hline \multirow[t]{2}{*}{$\mathrm{NO}$} & \multirow{2}{*}{$\begin{array}{l}\text { Aspek yang Di } \\
\text { Observasi }\end{array}$} & \multirow[t]{2}{*}{ Indikator Penilaian aktivitas Siswa } & \multicolumn{4}{|c|}{ Kriteria } \\
\hline & & & 1 & 2 & 3 & 4 \\
\hline & KOGNITIF & $\begin{array}{l}\text { 1. Siswa mampu menjelaskan gerak } \\
\text { dasar lompat } \\
\text { 2. Siswa dapat menjelaskan cara } \\
\text { melakukan gerak dasar lompat } \\
\text { dengan menggunakan tali } \\
\text { 3. Siswa dapat menyebutkan fungsi dari } \\
\text { gerak dasar lompat }\end{array}$ & & & & \\
\hline & \multicolumn{2}{|l|}{ Jumlah } & & & & \\
\hline & \multicolumn{2}{|c|}{ Jumlah Skor Maksimal : 12} & & & & \\
\hline
\end{tabular}

Nilai $=\frac{\text { Jumlah Skor yang diproleh }}{\text { Jumlah Skor Maksimal }} \times 100$

\begin{tabular}{|c|c|c|c|c|c|c|}
\hline \multirow[t]{2}{*}{ No } & \multirow{2}{*}{$\begin{array}{c}\text { Aspek yang Di } \\
\text { Observasi }\end{array}$} & \multirow[t]{2}{*}{ Indikator Penilaian aktivitas SIswa } & \multicolumn{4}{|c|}{ Kriteria } \\
\hline & & & 1 & 2 & 3 & 4 \\
\hline & AFEKTIF & $\begin{array}{l}\text { 1. Siswa dapat bekerja sama dengan } \\
\text { teman selama pembelajaran } \\
\text { berlangsung } \\
\text { 2. Siswa dapat bersikap sportif selama } \\
\text { pembelajaran berlangsung } \\
\text { 3. Siswa berani dalam melakukan } \\
\text { Practice gerak yang di instruksikan } \\
\text { oleh guru. }\end{array}$ & & & & \\
\hline & \multicolumn{2}{|l|}{ Jumlah } & & & & \\
\hline & \multicolumn{2}{|c|}{ Jumlah Skor Maksimal : 12} & & & & \\
\hline
\end{tabular}

Nilai $=\frac{\text { Jumlah Skor yang diproleh }}{\text { Jumlah Skor Maksimal }} \times 100$ 


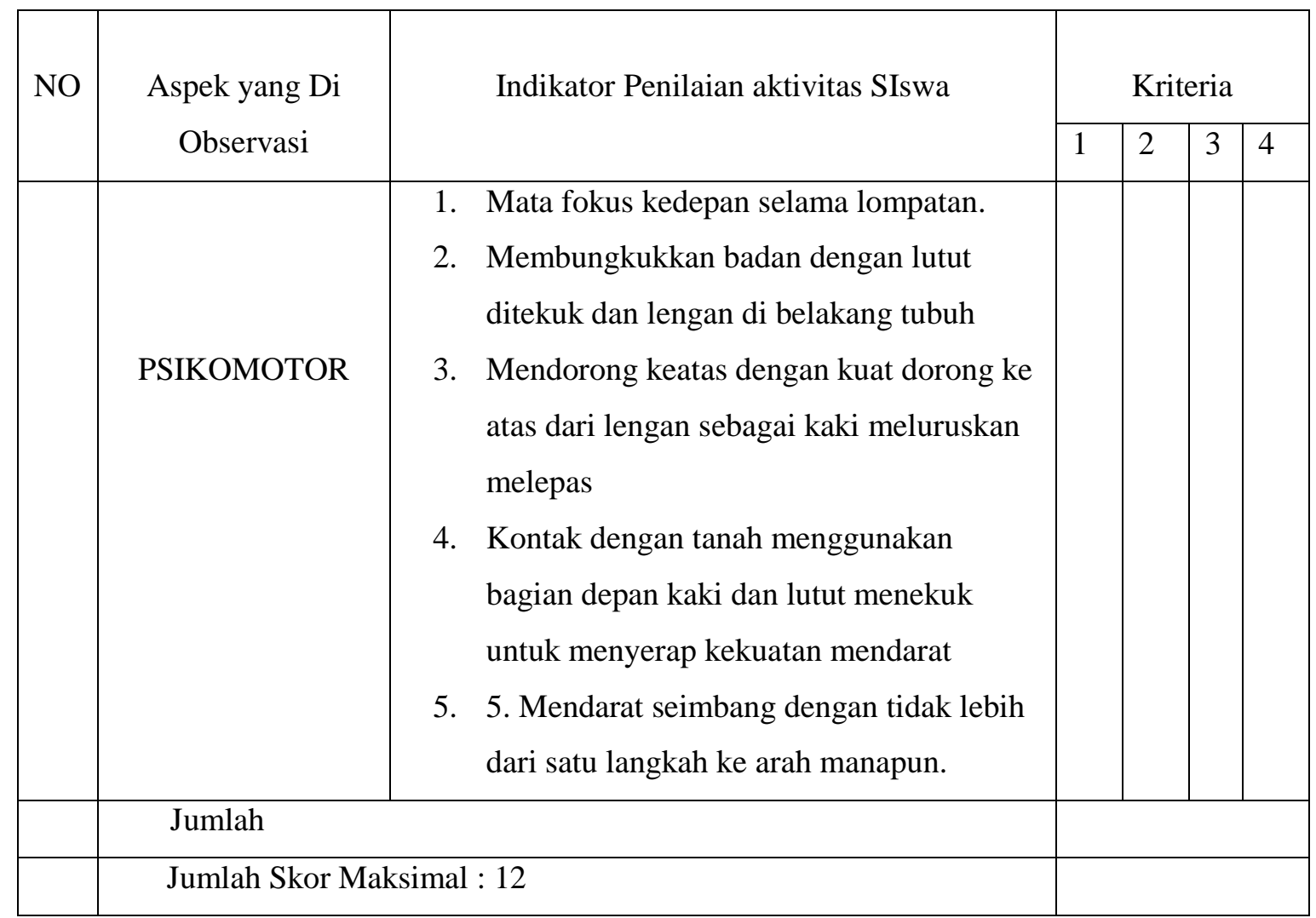

Diadaptasi dari Stephen Elder, Fundamental Motor Skills: A Manual for Classroom Teachers, 2009

Nilai $=\frac{\text { Jumlah Skor yang diproleh }}{\text { Jumlah Skor Maksimal }} \times 100$

Data tes dianalisis dengan menggunakan rata-rata nilai dan persentase ketuntasan belajar. KKM SDN Sukarela 01 untuk pelajaran gerak dasar lompat 70, maka siswa dikatakan tuntas belajar secara individu apabila siswa telah mencapai nilai 70 ke atas. Secara klasikal proses pembelajaran dikatakan tuntas apabila siswa di kelas memperoleh nilai 70 ke atas sebanyak 85, Depdiknas (2006).

Rumus perhitungan nilai hasil tes sebagai berikut:

a) Nilai Rata-Rata

$\bar{X}=\frac{\sum X}{N}$

Keterangan:

- $\bar{X} \quad=$ Rata-Rata Nilai Siswa

- $\sum X=$ Jumlah Keseluruhan Nilai Siswa

- $\quad N$ = Jumlah Siswa Keseluruhan, Sudjana (2009: 109) 
b) Ketuntasan Belajar Secara Klasikal

$K B=\frac{N S}{N} \times 100$

Keterangan:

- $\mathrm{KB}=$ Presentase Ketuntasan Belajar Klasikal

- $\quad \mathrm{NS}=$ Jumlah siswa yang mencapai nilai $\geq 70$

- $\quad \mathrm{N}=$ Jumlah Siswa

Tabel 3. Interval Ketuntasan Belajar Klasikal

\begin{tabular}{|c|c|}
\hline Interval & Kategori \\
\hline $90-100$ & Sangat Tinggi \\
\hline $70-89,9$ & Tinggi \\
\hline $50-69,9$ & Cukup \\
\hline $30-49,9$ & Rendah \\
\hline $10-29,9$ & Sangat Rendah \\
\hline
\end{tabular}

Indikator keberhasilan hasil belajar dalam penelitian ini adalah, sebagai berikut:

a. Nilai hasil evaluasi yang diperoleh siswa rata-rata mencapai $\geq 75$

b. Apabila siswa yang mendapat nilai $\geq 75$ mencapai 85, maka ketuntasan belajar klasikal tercapai.

\section{HASIL PENELITIAN}

Penelitian ini dilaksanakan dalam dua siklus dan masing-masing siklus dua kali perlakuan atau tindakan yang disesuaikan dengan jadwal mata pelajaran Penjas yaitu hari Rabu. Satu pertemuan berlangsung selama 2x45 menit. Untuk memperoleh data-data yang akurat tentang tindakan kelas ini maka peneliti mengadakan observasi awal terhadap subyek penelitian sebagai data awal kriteria dasar untuk penilaian dalam penelitian ini, disamping itu selama ini peneliti hanya melihat gejala rendahnya keterampilan gerak dasar lompat pada sebagian besar siswa, untuk lebih jelasnya hasil penelitian tindakan kelas ini dapat dideskripsikan sebagai berikut.

Siklus I Tindakan I, Pada tahap ini kegiatan yang dilaksanakan berdasarkan perencanaan tindakan yang telah ditetapkan. adalah meningkatkan hasil keterampilan melompat pada siswa kelas III (tiga). Pembelajaran dilakukan pada hari Rabu tanggal 30 
November 2016, pembelajaran dimulai pada pukul 07:00 - 08: 30 WIB di Lapangan depan SD Negeri Sukrela 01 Kota Bandung.

\section{Aspek Kognitif}

Berdasarkan aspek kognitif, pengetahuan dan pemahaman dalam melakukan lompat belum mengalami peningkatan yang signifikan atau jika dirata-ratakan sebesar 40,1 dengan kondisi ini maka pengetahuan dan pemahaman siswa perlu ditingkatkan dengan presentase minimal sebesar 34,9 dari 75 indikator kinerja yang diharapkan atau jika dirinci satupersatu indikator penilaiannya maka akan diperoleh hasilnya sebagai berikut:

a. Siswa mampu menjelaskan gerak dasar lompat rata-rata adalah 38,3, peningkatannya minimal sebesar 36,7 dari indikator kinerja 75.

b. Siswa dapat menjelaskan cara melakukan gerak dasar lompat dengan menggunakan tali rata-rata adalah 42,2, peningkatannya minimal sebesar 32,8 dari indikator kinerja 75.

c. Siswa dapat menyebutkan fungsi dari gerak dasar lompat rata-rata adalah 39,8, peningkatannya minimal sebesar 35,2 dari indikator kinerja 75 .

\section{Aspek Afektif}

Berdasarkan aspek afektif, sikap dan minat para siswa dalam lompat belum mengalami peningkatan yang signifikan atau masih rendah, jika dirata-ratakan sebesar 45,6 dengan kondisi ini maka sikap dan minat siswa perlu ditingkatkan dengan presentase minimal sebesar 29,4 dari 75 indikator kinerja yang diharapkan atau jika dirinci satupersatu indikator penilaiannya maka akan diperoleh hasilnya sebagai berikut:

a. Siswa dapat bekerja sama dengan teman selama pembelajaran berlangsung rata-rata adalah 44,5, peningkatannya minimal sebesar 30,5 dari indikator kinerja 75 .

b. Siswa dapat bersikap sportif selama pembelajaran berlangsung rata-rata adalah 53,1 , peningkatannya minimal sebesar 21,9 dari indikator kinerja 75 .

c. Siswa berani dalam melakukan Practice gerak yang di instruksikan oleh guru ratarata adalah 39,1, peningkatannya minimal sebesar 35,9 dari indikator kinerja 75 .

\section{Aspek Psikomotor}

Berdasarkan aspek psikomotor keterampilan gerak dasar siswa dalam melakukan lompat belum mengalami peningkatan yang signifikan atau jika dirata-ratakan sebesar 44,54 dengan kondisi ini maka kemampuan siswa perlu ditingkatkan dengan presentase minimal sebesar 30,46 dari 75 indikator kinerja yang diharapkan atau jika dirinci satupersatu indikator penilaiannya maka akan diperoleh hasilnya sebagai berikut:

a. Mata fokus kedepan selama lompatan rata-rata adalah 37,5, peningkatannya minimal sebesar 37,5 dari indikator kinerja 75.

b. Membungkukkan badan dengan lutut ditekuk dan lengan di belakang tubuh rata-rata adalah 47,7, peningkatannya minimal sebesar 27,3 dari indikator kinerja 75 .

c. Mendorong keatas dengan kuat dorong ke atas dari lengan sebagai kaki meluruskan melepas rata-rata adalah 48,4, peningkatannya minimal sebesar 26,6 dari indikator kinerja 75. 
d. Kontak dengan tanah menggunakan bagian depan kaki dan lutut menekuk untuk menyerap kekuatan mendarat rata-rata adalah 42,2, peningkatannya minimal sebesar 32,8 dari indikator kinerja 75 .

e. Mendarat seimbang dengan tidak lebih dari satu langkah ke arah manapun rata-rata adalah 46,9, peningkatannya minimal sebesar 28,1 dari indikator kinerja 75 .

Siklus I Tindakan II, pada tahap ini kegiatan yang dilaksanakan berdasarkan perencanaan tindakan yang telah ditetapkan. adalah meningkatkan hasil keterampilan lompat pada siswa kelas III (tiga). Pembelajaran dilakukan pada hari Rabu tanggal 07 Desember 2016, pembelajaran dimulai pada pukul 07:00 - 08: 30 WIB di Lapangan depan SD Negeri Sukrela 01 Kota Bandung.

\section{Aspek Kognitif}

Berdasarkan aspek kognitif, pengetahuan dan pemahaman dalam melakukan lompat telah mengalami peningkatan, jika dirata-ratakan sebesar 50,8 dengan kondisi ini maka pengetahuan dan pemahaman siswa perlu ditingkatkan dengan presentase minimal sebesar 24,2 dari 75 indikator kinerja yang diharapkan atau jika dirinci satupersatu indikator penilaiannya maka akan diperoleh hasilnya sebagai berikut:

a. Siswa mampu menjelaskan gerak dasar lompat rata-rata adalah 49,2, peningkatannya minimal sebesar 25,8 dari indikator kinerja 75 .

b. Siswa dapat menjelaskan cara melakukan gerak dasar lompat dengan menggunakan tali rata-rata adalah 52,3, peningkatannya minimal sebesar 22,7 dari indikator kinerja 75.

c. Siswa dapat menyebutkan fungsi dari gerak dasar lompat rata-rata adalah 50,8, peningkatannya minimal sebesar 24,2 dari indikator kinerja 75 .

\section{Aspek Afektif}

Berdasarkan aspek afektif, sikap dan minat para siswa dalam lompat telah mengalami peningkatan, jika dirata-ratakan sebesar 56 dengan kondisi ini maka sikap dan minat siswa perlu ditingkatkan dengan presentase minimal sebesar 19 dari 75 indikator kinerja yang diharapkan atau jika dirinci satupersatu indikator penilaiannya maka akan diperoleh hasilnya sebagai berikut:

a. Siswa dapat bekerja sama dengan teman selama pembelajaran berlangsung rata-rata adalah 53,9, peningkatannya minimal sebesar 21,1 dari indikator kinerja 75 .

b. Siswa dapat bersikap sportif selama pembelajaran berlangsung rata-rata adalah 60,9 , peningkatannya minimal sebesar 14,1 dari indikator kinerja 75 .

c. Siswa berani dalam melakukan Practice gerak yang di instruksikan oleh guru ratarata adalah 53,1, peningkatannya minimal sebesar 21,9 dari indikator kinerja 75 .

\section{Aspek Psikomotor}

Berdasarkan aspek psikomotor keterampilan gerak dasar siswa dalam melakukan lompat telah mengalami peningkatan namun tidak signifikan atau jika dirata-ratakan 
sebesar 44,54 dengan kondisi ini maka kemampuan siswa perlu ditingkatkan dengan presentase minimal sebesar 30,46 dari 75 indikator kinerja yang diharapkan atau jika dirinci satupersatu indikator penilaiannya maka akan diperoleh hasilnya sebagai berikut:

a. Mata fokus kedepan selama lompatan rata-rata adalah 53,9, peningkatannya minimal sebesar 21,1 dari indikator kinerja 75.

b. Membungkukkan badan dengan lutut ditekuk dan lengan di belakang tubuh rata-rata adalah 48,4, peningkatannya minimal sebesar 26,6 dari indikator kinerja 75 .

c. Mendorong keatas dengan kuat dorong ke atas dari lengan sebagai kaki meluruskan melepas rata-rata adalah 53,1 , peningkatannya minimal sebesar 21,9 dari indikator kinerja 75.

d. Kontak dengan tanah menggunakan bagian depan kaki dan lutut menekuk untuk menyerap kekuatan mendarat rata-rata adalah 46,1, peningkatannya minimal sebesar 28,9 dari indikator kinerja 75.

e. Mendarat seimbang dengan tidak lebih dari satu langkah ke arah manapun rata-rata adalah 50,8, peningkatannya minimal sebesar 24,2 dari indikator kinerja 75 .

Siklus II Tindakan I, Pada tahap ini kegiatan yang dilaksanakan berdasarkan perencanaan tindakan yang telah ditetapkan. adalah meningkatkan hasil keterampilan melompat pada siswa kelas III (tiga). Pembelajaran dilakukan pada hari Rabu tanggal 14 Desember 2016, pembelajaran dimulai pada pukul 07:00 - 08: 30 WIB di Lapangan depan SD Negeri Sukrela 01 Kota Bandung.

\section{Aspek Kognitif}

Berdasarkan aspek kognitif, pengetahuan dan pemahaman dalam melakukan lompat telah mengalami peningkatan, jika dirata-ratakan sebesar 61,7 dengan kondisi ini maka pengetahuan dan pemahaman siswa perlu ditingkatkan dengan presentase minimal sebesar 13,3 dari 75 indikator kinerja yang diharapkan atau jika dirinci satupersatu indikator penilaiannya maka akan diperoleh hasilnya sebagai berikut:

a. Siswa mampu menjelaskan gerak dasar lompat rata-rata adalah 62,5, peningkatannya minimal sebesar 12,5 dari indikator kinerja 75.

b. Siswa dapat menjelaskan cara melakukan gerak dasar lompat dengan menggunakan tali rata-rata adalah 62,5, peningkatannya minimal sebesar 12,5 dari indikator kinerja 75.

c. Siswa dapat menyebutkan fungsi dari gerak dasar lompat rata-rata adalah 60,2, peningkatannya minimal sebesar 14,8 dari indikator kinerja 75 .

\section{Aspek Afektif}

Berdasarkan aspek afektif, sikap dan minat para siswa dalam lompat telah mengalami peningkatan, jika dirata-ratakan sebesar 63,5 dengan kondisi ini maka sikap dan minat siswa perlu ditingkatkan dengan presentase minimal sebesar 11,5 dari 75 indikator kinerja yang diharapkan atau jika dirinci satupersatu indikator penilaiannya maka akan diperoleh hasilnya sebagai berikut:

a. Siswa dapat bekerja sama dengan teman selama pembelajaran berlangsung rata-rata adalah 64,8, peningkatannya minimal sebesar 10,2 dari indikator kinerja 75 . 
b. Siswa dapat bersikap sportif selama pembelajaran berlangsung rata-rata adalah 63,3 , peningkatannya minimal sebesar 11,7 dari indikator kinerja 75 .

c. Siswa berani dalam melakukan Practice gerak yang di instruksikan oleh guru ratarata adalah 62,5, peningkatannya minimal sebesar 12,5 dari indikator kinerja 75.

Aspek Psikomotor

Hasil dari refleksi yang dilakukan berdasarkan aspek psikomotor yaitu bahwa keterampilan gerak dasar siswa dalam melakukan lompat telah mengalami peningkatan meskipun belum mampu memenuhi nilai rata-rata ketuntasan minimal yaitu sebesar 60,48 . Berdasarkan dengan kondisi tersebut maka kemampuan siswa perlu ditingkatkan dengan presentase minimal sebesar 14,52 dari 75. Indikator kinerja yang diharapkan atau jika dirinci satupersatu indikator penilaiannya maka akan diperoleh hasilnya sebagai berikut:

a. Mata fokus kedepan selama lompatan rata-rata adalah 60,2 , peningkatannya minimal sebesar 14,8 dari indikator kinerja 75 .

b. Membungkukkan badan dengan lutut ditekuk dan lengan di belakang tubuh rata-rata adalah 60,9, peningkatannya minimal sebesar 14,1 dari indikator kinerja 75 .

c. Mendorong keatas dengan kuat dorong ke atas dari lengan sebagai kaki meluruskan melepas rata-rata adalah 59,4, peningkatannya minimal sebesar 15,6 dari indikator kinerja 75.

d. Kontak dengan tanah menggunakan bagian depan kaki dan lutut menekuk untuk menyerap kekuatan mendarat rata-rata adalah 61,7, peningkatannya minimal sebesar 13,3 dari indikator kinerja 75.

e. Mendarat seimbang dengan tidak lebih dari satu langkah ke arah manapun rata-rata adalah 60,2, peningkatannya minimal sebesar 14,8 dari indikator kinerja 75 .

Siklus II Tindakan II, pada tahap ini kegiatan yang dilaksanakan berdasarkan perencanaan tindakan yang telah ditetapkan, yaitu meningkatkan hasil keterampilan melompat pada siswa kelas III (tiga). Pembelajaran dilakukan pada hari Rabu tanggal 21 Desember 2016, pembelajaran dimulai pada pukul 07:00 - 08: 30 WIB di Lapangan depan SD Negeri Sukarela 01 Kota Bandung.

Hasil data yang diperoleh pada pengamatan siklus dua tindakan dua dimana menunjukkan rata-rata siswa telah memiliki pengetahuan, pemahaman dan penerapan gerak dasar lompat. Selain itu pula, para siswa memiliki minat yang tinggi terhadap lompat tali, dan juga keterampilan gerak dasar lompat yang telah memenuhi standar indikator kinerja, dengan kata lain bahwa rata-rata dalam aspek kognitif, afektif dan psikomotor sudah meningkat signifikan dari siklus dan tindakan sebelumnya.

Berdasarkan hasil dari pada pengamatan observasi awal di mana rata-rata pada aspek kognitif dalam pengetahuan dan pemahaman gerak dasar lompat siswa adalah 37,5, pada siklus satu tindakan satu sebesar 40,1, siklus satu tindakan dua sebesar 50,8, siklus dua tindakan satu sebesar 61,7, dan siklus dua tindakan dua sebesar 76,8. Hal tersebut jelas menunjukan bahwa siswa mengalami peningkatan dalam pemahaman dan pengetahuan gerak dasar dari mulai observasi awal hingga siklus dua tindakan dua. 
Sedangkan, hasil dari pada pengamatan observasi awal di mana rata-rata pada aspek afektif dalam minat dan sikap gerak dasar lompat siswa adalah 35,1, pada siklus satu tindakan satu sebesar 45,6, siklus satu tindakan dua sebesar 56, siklus dua tindakan satu sebesar 63,5, dan siklus dua tindakan dua sebesar 77,1. Hal tersebut jelas menunjukan bahwa siswa mengalami peningkatan dalam minat dan sikap gerak dasar dari mulai observasi awal hingga siklus dua tindakan dua.

Hasil dari aspek psikomotor, keterampilan gerak dasar lompat siswa adalah 38,28, pada siklus satu tindakan satu keterampilan gerak lompat sebesar 44,54, siklus satu tindakan dua sebesar 50,46, siklus dua tindakan satu sebesar 60,48, dan siklus dua tindakan dua sebesar 76,56. Hal tersebut jelas menunjukan bahwa siswa mengalami peningkatan keterampilan gerak dasar dari mulai observasi awal hingga siklus dua tindakan dua.

\section{KESIMPULAN}

Berdasarkan hasil pengolahan dan analisis data maka dapat disimpulkan bahwa dengan penerapan gaya praktek melalui aktivitas lompat tali dapat meningkatkan hasil belajar lompat pada siswa kelas III SDN Sukarela 1 Kota Bandung. Hasil belajar lompat pada siswa mengalami peningkatan pada setiap tindakan dan siklusnya. Peningkatan hasil belajar lompat, baik pada siswa laki-laki maupun perempuan pada hasil siklus II tindakan II, sudah mencapai target pencapaian hasil belajar yaitu lebih dari 75. Dengan demikian, penerapan gaya praktek melalui aktivitas lompat tali dapat meningkatkan hasil belajar lompat pada siswa kelas III di SDN Sukarela 1 Kota Bandung. 


\section{REFERENSI}

Arikunto, Suharsimi. 2002. Metodologi Penelitian. Penerbit. Jakarta: Rineka Cipta

Arikunto, Suharsimi. 2006. Prosedur Penelitian Suatu Pendekatan Praktik. Jakarta:

Rineka Cipta

Chaeunyoung (2005). Fun Jump Rope. Korea

Departemen Pendidikan Nasional, 2007. Peraturan Menteri Pendidikan Nasional

Nomor 41 Tahun 2007, tentang Standar Proses, Jakarta: Depdiknas.

Depdiknas. (2006). Kurikulum Tingkat Satuan Pendidikan (KTSP). Jakarta:

Departemen Pendidikan Nasional

Graham, et. all. (2007). Children Moving: A Reflective Approach to Teaching Physical Education. USA: Mc. Graw-Hill Companies, Inc.

Hidayat, Yusuf. (2011). Materi Penelitian Tindakan Kelas. FPOK UPI Bandung dan

Direktorat Pembinaan Diklat Ditjen PMPTK. dan

Kemendikbud. (2013). Kerangka Dasar Kurikulum 2013, Kementerian Pendidikan

Kebudayaan Direktorat Jenderal Pendidikan Dasar. Jakarta

KTSP. (2006). Kurikulum Tingkat Satuan Pendidikan (KTSP) SD dan MI Mata Pelajaran: Pendidikan Jasmani, Olahraga dan Kesehatan. Jakarta: Depdiknas.

Lee, F. C. (2010). The Effects of Forty-Weeks Jumping Rope Exercise Intervention on Physical Fitness of Elementary School Students. Unpublished Master's Thesis. Pingtung: National Pingtung University of Education. The Journal of Human Resource and Adult Learning, Vol. 8, Num. 1, June 2012

Masterson, G. L. (1993). Effects of Weighted Rope Jump Training on Power Performance Tests in Collegians. Journal of Strength and Conditioning Research, The Journal of Human Resource and Adult Learning, Vol. 8, Num. 1, June 2012

Mosston (1994). Teaching Physical Education. First Online Edition, 2008.

Stephen Elder. (2009). Fundamental Motor Skills: A Manual for Classroom Teachers.

Sujiono Bambang, 2007. Metode Pengembangan Fisik. Jakarta: Pusat Penerbit Universitas Terbuka.

Sukintaka. (1992). Teori Bermain. Jakarta: Depdikbud.

Syu, S. F. (2010). The influence of rope skipping on health related physical fitness of elementary school students -A case study of liu-ying elementary school in Tainan County. Unpublished Master's Thesis. Taichung: Asia University. The Journal of Human Resource and Adult Learning, Vol. 8, Num. 1, June 2012

Tsai, Y. H. (2009). Effect of Rope Jumping Training on The Health Related Physical Fitness of Tudents With Amblyopia. Unpublished Master's Thesis. Taipei: National Taiwan Normal University. The Journal of Human Resource and Adult Learning, Vol. 8, Num. 1, June 2012

Mahboobeh S. J. dan Mandana (2015), "The Effect of Jump-Rope Training on The Physical Fitness of 9 to 10 Years Old Female Students"

http://www.imedpub.com/articles/the-effect-of-jumprope-training-on-the-physical-fitnessof-9-to-10years-old-female-students.pdf , 11 December 2016 
Mahendra, A. (2007). Teori Belajar Mengajar Motorik. Bandung: FPOK Universitas Pendidikan Indonesia.

Mojtaba B. G., Parivash N. and Hossein S. (2014), "Effects of Speedy and Demonstration Jumping-Rope Training on Gross Motor Skills” Journal Volume-3 Issue4, http://sciencejournal.in/data/documents/Life-Science-Vol-3-4-43.pdf, 11 December 2016 